\title{
ASSESSMENT OF FINANCIAL TECHNOLOGY SERVICES FOR VALUE CO-CREATION OR VALUE CO-DESTRUCTION IN EMERGING ECONOMIES: ISPAR MODEL
}

\author{
Nida Qamar, Ashfaq Ahmad and Sadia Farooq \\ Hailey College of Commerce, University of the Punjab, Pakistan
}

\begin{abstract}
Financial Technology (FinTech) has made the lives of customers easier by a combination of the technological and financial sectors, eventually enabling the promotion of Branchless Banking. Pakistan has seen the rapid adoption of Branchless Banking (BB) in the past decade that is evident from encouraging trends during the financial year 2020. However, the application of FinTech is at an evolutionary stage in the services sector, particularly in the banking industry. Service providers face the challenge to resolve the nuances of customers' journeys due to glitches still existing in BB. This study investigated the issues of FinTech based upon critical incidents that were identified by using netnographic methodology. NVivo 12 plus used for qualitative thematic analysis of the netnographic data. It helps to explore antecedents that may create value co-creation or value co-destruction and its consequences by adopting the ISPAR model of Service Science. Findings indicate that there are few common triggers of value co-destruction such as unhelpful service providers, fraud, nonprovision of services and similarly realization of value, quick feedback, instant resolution of the issue creating value co-creation respectively. This research provides an imputes to $B B$ service providers to focus on the identified antecedents of successful realization of value to thrive in this sector.
\end{abstract}

Key words: Financial Technology, Branchless Banking, Netnography, ISPAR model, Service Science.

Cite this Article: Nida Qamar, Ashfaq Ahmad and Sadia Farooq, Assessment of Financial Technology Services for Value Co-creation or Value Co-destruction in Emerging Economies: ISPAR Model, International Journal of Management, 11(9), 2020, pp. 238-256.

http://iaeme.com/Home/issue/IJM?Volume=11\&Issue=9

\section{INTRODUCTION}

Financial Technology (FinTech) is an emerging industry that makes innovative use of technology to have efficient financial services. The basic purpose is to reshape the financial 
service industry by improving quality and reshaping the financial landscape. FinTech emerged from the 2008 financial crisis by amalgamating internet technology, social media, big data analytics. FinTechs proposes a hybrid business model, operating in the technological and financial sector (Moro Visconti, 2020).

FinTech represents one of the digital platforms that enable the digital client to innovate financial intermediaries. Digital platforms impact the way participants work together. Digitalization is defined as "the concept of 'going paperless', namely as the technical process of transforming analog information or physical products into digital form" (Moro Visconti, 2020).

Digitalization helps in digital transformation, which is applying digital technology in solving traditional problems. Digital transformation helps in enhancing creativity and innovation, at the same time revising and augmenting customary methods.

FinTech business models work in:

- Catalyzing/upgrading the business models for optimal business and enriching the process of traditional banks.

- Founder of innovative products/services normally via the B2B channel (Moro Visconti, 2020).

Pakistan is an ideal country for FinTech, as the country has a massive unbanked population.

A customers' journey is the path it travels to satisfy its needs and wants and will typicallyconsist of several separate processes. Customers find their journey difficult with conventional banks meeting many procedures for the tasks, FinTech makes it seamless and more pleasing. The services should match with the characteristic of the customers, but these similarities do not exist in developing countries. This requires the assessment of the needs and wants of the local customers by speaking to them and even visiting local villagers for their products and services. However, low financial inclusion and low financial illiteracy are the main hurdles in paving the path to avail financial services in countries like Pakistan.

Financial inclusion can be increased by making financial products and services easy to use, it may introduce financial products to more public. World Bank and OECD have researched that lack of financial literacy linked with a lack of financial inclusion (Abidin \& Roziana, 2019). FinTech has the potential to increase financial literacy (Buckley \& Webster, 2016). Hence, FinTech takes customers to understanding of financial concepts. These are the important issues that must be considered while finding the solution keeping the FinTech problems particularly in developing economies. Developed countries face challenges in terms of low financial quality, financial exclusion, and low financial literacy. The rigid system of banks itself hinders the access of financial services especially to remote areas where people can't come to cities for their monetary transactions. Brick and mortar banks are not present in villages because it is costly for banks as well to open a large number of their branches in areas where demand and population clientage is low. Therefore, the geographic distance poses a great financial cost (in terms of transportation cost, monitoring cost) that ultimately increases the high rate for credit. Loan repayment is also an issue for the villagers who especially do farming (Meyer \& Schwager, 2007).

Hefty documentation is required to open an account, informal financial institutions and poor segments with very low income are unable to open their accounts (Rojas-Suarez, 2010). FinTech has a great opportunity to provide relief by touching the pain points of customers who have low access to formal financial institutions. More avenues have opened where customers can better get acquainted with micro lenders. Behr, Entzian, and Güttler (2011) suggest that it would reduce information asymmetry and also transaction costs. 
FinTech services in Pakistan as provided by the State bank of Pakistan are given in

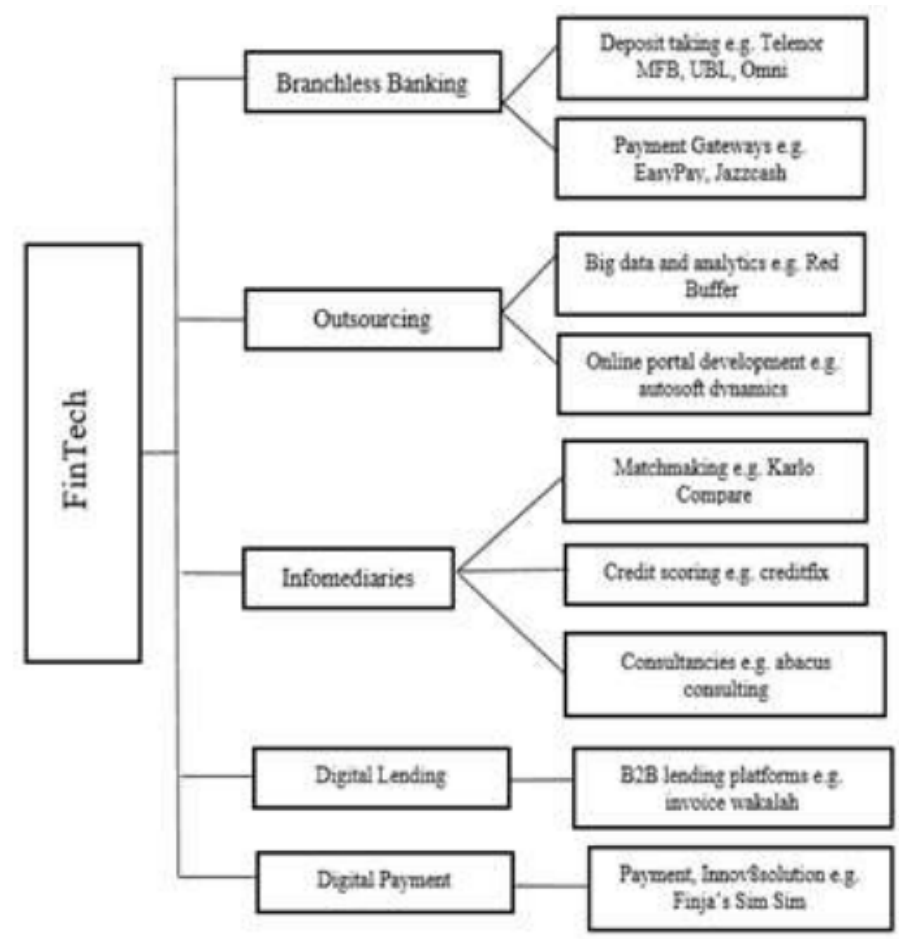

Figure 1 Classification of FinTech companies in Pakistan. (Adapted from State Bank of Pakistan).

The focus of this paper is on Branchless Banking which is one of the categories of FinTech. Branchless Banking has played a significant role in providing financial facilities to masses. It is called "banking beyond branches" as financial services are availed beyond financial institutions (Clark, 2020). BB is defined as "Branchless Banking is a distribution network that is used to provide financial services outside bank branch offices through alternative technology and networks in a cost-effective, efficient as well as safe, and comfortable condition" (Kustina, Dewi, Prena, \& Suryasa, 2019, p. 172). Branchless banking has paved the path for making micropayments and credits easier for the microfinance sector and decreased the dependability in hefty procedures of traditional banks (Qazi \& Khushk, 2019). Branchless banking is increasing significantly in Pakistan, the following are the Branchless Banking providers according to State bank of Pakistan.

Table 1 Agent location with account opening capability

\begin{tabular}{clccc}
\hline S. No & \multicolumn{1}{c}{ BB provider* } & $\begin{array}{c}\text { total no. of } \\
\text { agents }\end{array}$ & Jul-Sept 2018 & Oct-Dec 2018 \\
\hline 1 & Omni & 35866 & $100 \%$ & $100 \%$ \\
2 & JS Bank & 28474 & $110 \%$ & $100 \%$ \\
3 & Paymax & 44775 & $47 \%$ & $52 \%$ \\
4 & JazzCash & 78582 & $47 \%$ & $46 \%$ \\
5 & HBL Express & 37503 & $44 \%$ & $43 \%$ \\
6 & Easypaisa & 130020 & $27 \%$ & $28 \%$ \\
7 & Upaisa & 39657 & $0 \%$ & $2 \%$ \\
8 & Meezan Upaisa & 90313 & $88 \%$ & $89 \%$ \\
9 & Others+ & 425199 & $42 \%$ \\
\hline \multicolumn{7}{c}{} \\
\hline
\end{tabular}

Source: State Bank of Pakistan, Branchless Banking report 2018. 
In Pakistan, services like Easy paisa and Jazz Cash have eradicated the distances and made transactions cost quite less just by using the mobile. Customers can install apps on their phones and deposit amount on their account. To send funds sender can send money by using a specific tab on their app to enter the recipient's phone number and send the required amount. On receiving the amount, the recipient can keep the amount in the phone or withdraw by physically visiting the agent. Customers can avail the services by just having SMS enabled phone. This s a great step in developing countries like Pakistan. The rate of increase of BB is very high in Pakistan (Zaffar, Kumar, \& Zhao, 2019) as shown in table 2. State Bank of Pakistan has played a significant role in impacting its growth (Waqas, Hamzah, \& Salleh, 2020).

Table 2 Branchless Banking statistics (Jan-Mar 2020) by State Bank of Pakistan

\begin{tabular}{lcc}
\hline \multicolumn{1}{c}{ Indicators } & Oct-Dec 19 & Jan-Mar 20 \\
\hline Number of Agents & 437,182 & 434,192 \\
Number of Active BB Agents & 189.991 & 193,291 \\
Number of Accounts & $46,103,017$ & $48,345,517$ \\
Number of Active Accounts & $24,529,731$ & $27,737,457$ \\
Deposits as on Quarter end & 28,770 & 31,935 \\
(Rs. In millions) & & \\
Number of transactions during the quarter (number & 363,546 & 407,258 \\
in '000') & & \\
Value of transactions during the quarter (Rs.In & $1,197,115$ & $1,292,313$ \\
millions) & & \\
Average size of transactions (in Rs.) & 3,293 & 3,173 \\
Average daily transactions (numbers) & $4,039,399$ & 4.525 .085 \\
\hline Average deposit in accounts (Rs.) & 624 & 661 \\
\hline
\end{tabular}

BB is significantly impacting financial inclusion and it has a major role in increasing financial literacy (Chen \& Divanbeigi, 2019). Pakistan has one of the worst financial inclusion in the world. Therefore, BB is at a better pedestal to increase the country's position better in terms of financial inclusion. However, knowing the customers' perspective to identify the issues faced is pivotal. Without getting to know the significant experiences of customers the branchless banking can't be improved.

The focus of contemporary economics is now on the service-oriented businesses, which takes IT integration within the business processes (Mora, Raisinghani, O'Connor, \& Gelman, 2009). The new phenomenon in services gave rise to service science in 2004. IBM introduced the interdisciplinary specialization of system science and organizational theory (Ackoff, 1971). Service science still needs its full application in other fields as well. BB has made the lives of people easier. The Service-Dominant Logic lens helps in facilitating the value cocreation among the resource integrators (Vargo \& Lusch, 2004), therefore, this platform helps in the availability and accessibility of resources among the actors as well as the transferability of resources in the service system (Breidbach \& Ranjan, 2017). Thus, a noteworthy gap in knowledge exists. Theoretical insight into the service platform applying the concept of value co-creation is crucial in the digital service system perspective such as FinTech (Gummesson et al., 2014). Vargo and Lusch (2004) presented an opposing idea to Goods-Dominant Logic, a new dominant logic in marketing to introduce dynamic, intangible resources, and inputs for value co-creation which is called Service-Dominant (SD) logic. SD logic is defined as "a mindset, a lens through which to look at social and economic exchange phenomena so they can potentially be seen more clearly" (Vargo \& Lusch, 2004). Vargo and Lusch (2004) presented a novel approach to value co-creation by collaborating the efforts and integrating 
the resources of both the customer and service provider. Prahalad and Ramaswamy (2004) have explored the significance of value co-creation as mutual integration of resources between the beneficiary and service provider in the perspective of the changing paradigm of their interaction.

The standard model of service system is based on the different phases of the business processes and several possible outcomes known as the ISPAR model, Interact-ServicePropose-Agree-Realize. It has been estimated that any service interaction can have a dual role: value co-creation or value co-destruction (Borangiu, Oltean, Drăgoicea, e Cunha, \& Iacob, 2014).

Service Science depends upon ten foundational premises "resources, entities, access rights, value co-creation interaction, governance interaction, outcomes, stakeholders, measures, networks and ecology"(Maglio \& Spohrer, 2008, p. 72). These interactions are based on value propositions where it is institutively promised that value co-creation will be realized (Maglio \& Spohrer, 2008). The ISPAR model facilitates possible outcomes that can be considered as outcomes of the service decision process. The organization process composes of two major systems: the management system and production system which consist of business processes such c as quality control, operations, and information system (Mora, Gelman, Cervantes, Mejía, \& Weitzenfeld, 2003).

Firstly, the value propositions are formed by the provider, after then service process enters into the value proposition based interaction where the provider and recipient of services negotiate and set the value proposition terms. Both parties come to some interaction where the expertise are provided by the provider against the needs and wants of the customer. Customer pays the cost of service against the service received (Borangiu et al., 2014).

Our present study relies on an analysis of antecedents that cause outcomes in the form of value co-creation and value co-destruction in the ISPAR model.

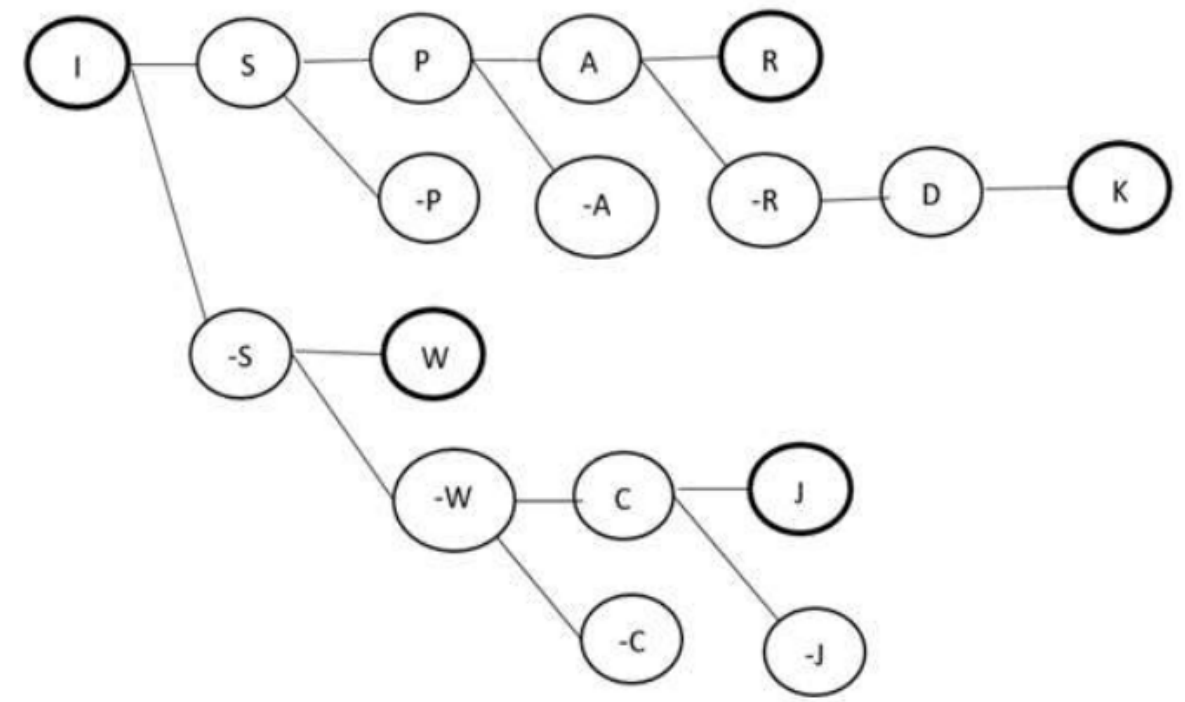

$\mathrm{I}=$ Interaction

$\mathrm{S}=$ Service interaction

$-\mathrm{S}=$ Not a service interaction

$\mathrm{P}=$ Proposal communicated

$-\mathrm{P}=$ Proposal not communicated

$\mathrm{A}=$ Agreement

$-\mathrm{A}=$ Agreement not reached 
Assessment of Financial Technology Services for Value Co-creation or Value Co-destruction in Emerging Economies: ISPAR Model

$\mathrm{R}=$ Realized value co-creation

$-\mathrm{R}=$ Not realized value co-creation (as judged by one or both service systems, or another interested service system stakeholder)

$\mathrm{D}=$ Dispute

$-\mathrm{D}=$ Not disputed

$\mathrm{K}=\mathrm{OK}$ resolution for all interested

$-\mathrm{K}=$ Not $\mathrm{OK}$ resolution for interested

$\mathrm{W}=$ Welcome non-service interaction

$-\mathrm{W}=$ Not welcome non-service interaction

$\mathrm{C}=$ Criminal (illegal) interaction

$-\mathrm{C}=$ Not criminal interaction

$\mathrm{J}=$ Justice realized

$-\mathrm{J}=$ No justice realized

Figure 2 ISPAR descriptive model (Adopted from Maglio, P. P., Vargo, S. L., Caswell, N., \& Spohrer, J., 2009)

There can be 10 outcomes based on the ISPAR model. The focus of this study is only on $\mathrm{R}, \mathrm{K}, \mathrm{W},-\mathrm{P},-\mathrm{A},-\mathrm{K}$ only. Either the value proposition is accepted or not (-A or -P). Based on this outcome the value proposition can be negotiated for modification and then service process is initiated, it then goes back to the value proposition based interaction phase. If the value proposition is not modified due to any reason, this negotiation is failed and the process is halted at that point and the information is stored for further business decision (-A). Now if there is acceptance of value proposition the service cycle enters into the service "contracting" and "delivery" phase, service is contracted and used by customers. The service contract and delivery are evaluated by stakeholders and that's all happens in the service evaluation phase. If the evaluation matches or exceeds the expectations from both sides, then it can be considered as value co-creation interaction. If the value is co-created, then the information is stored for future business decisions. And the process stops as value is realized here (R). If value co-creation has not occurred, then the service process enters into another phase where reasons for failure are analyzed. If the value is not created, the reasons for the failure are analyzed. If a dispute arises then they can be legally resolved ( $\mathrm{K}$ or $-\mathrm{K})$. however there is no dispute (-D) then there are chances that service can be improvised and the service process lifecycle can be returned to a new phase of the value proposition (Borangiu et al., 2014).

Social media platforms have led the service providers and consumers to build jointly the real-time customers' experiences by using new information (Waqas et al., 2020). For this reason, this new interactive media is gaining increasing importance for understanding the customer experience (Hsu \& Yen, 2016). Customer experience is the emotional and cognitive response to online interactivity between customers and brand has become of recent academic interest (Waqas et al., 2020). Despite all, still, marketers have not thoroughly dig out the customer experience in the context of social media to date (Waqas et al., 2020). Social media has given the power to customers from the managers to develop their version of brand meaning (Waqas et al., 2020), therefore its importance can't be ignored. The consumergenerated content can be expressed in various ways, however, in this study customers' experiences via comments of Facebook brand communities of BB companies are taken as data. Understanding the contents in the form of comments and reviews will help to understand the brand experience the focus is on the critical incidents experienced in availing the service. The critical incidents that either have ended in value co-creation and value co-destruction. Exploring the antecedents and consequences that create the above mentioned outcomes would help the brand managers to focus on increasing service quality and remove all the glitches. Thus, this study has adopted Service-Dominant Logic under the Service System adopts a 
consumer culture-based. By employing netnographic methodology, the posts, reviews, and comments are taken from brand communities of FinTech companies.

In summary, consumers have received greater access to financial services with the introduction of BB. It can also protect consumers by providing transparent procedures. On the other hand, consumers with low financial literacy availing financial services especially via using internet technology can get frustrated by the number of products and complexity increases, bad decisions, and bad actors. So there can be two sides of the same coin on any service interaction either interaction becomes successful and value is co-created among actors or value is not realized and no value co-creation occurs that may also lead to value codestruction. Usually, the major focus of service providers is to the point where value is realized i.e. value co-creation occurs. There is a need to focus on outcomes where value is codestructed as well. These are the outcomes which lose the customer and customer becomes hesitant to avail the service again due to bad decision. The study will help service providers to work on antecedents creating value co-creation and diminish value co-destruction factors in $\mathrm{BB}$. So the present study is concentrated on the following research questions:

- What are the antecedents of value co-creation and value co-destruction from the perspective of the ISPAR model in Branchless Banking services?

- What are the consequences of value co-creation and value co-destruction from the perspective of the ISPAR model in Branchless Banking services?

\section{LITERATURE REVIEW}

The general public lost its trust in the traditional banking industry after the Global Financial Crisis (GFC) of 2008 which led to the introduction of FinTech (Financial technology) (Breidbach \& Ranjan, 2017). The focus of FinTech is to go digital by making all processes streamline and making customers journey pleasant whereas traditional banks have tried to digitalized their process but in piecemeal. While one of the processes is digital, however, others offline. Therefore, the customers' journey is a mixture of online and offline processes. Thus, FinTech is better able to make customer's journey smooth and pleasant (Buckley \& Webster, 2016). Failure occurs when an insufficient understanding of the customer journey is there. Essential thing is to comprehend the difference between the process and journey. Processes are the steps that customers take to satisfy their needs and wants. In short, the journey comprises of various processes (Buckley \& Webster, 2016).

FinTech services have significant importance in Pakistan as the country has a huge unbanked population of around 100 million, according to the World Bank's Global Findex 2019 database. However, Branchless Banking has played a significant role in providing financial facilities to masses.

Branchless banking has paved the path for making micropayments and credits easier for the microfinance sector and decreased the dependability in hefty procedures of traditional banks (Qazi \& Khushk, 2019). Branchless Banking is an efficient mode to reach to people in remote areas where transactions by people are small, banking access is difficult (Kustina et al., 2019), areas with low population density, availing financial services is costly is done via formal banks and literacy rate is low (Buckley \& Webster, 2016). BB is technology based agent banking which not enables clients in depositing, transferring, and withdrawing of money but also facilitates them in paying their utility bills without visiting bank branches in person (Malik, 2020).

The financial services do not remain dependent on traditional bank office, rather can be carried out by using cell phones or other modes (Linsenmeier, Rosen, \& Rouse, 2006). The payment system under BB is conducted by using Electronic Data Capture (EDC), cellular 
phones, and third party agents to work unbanked (Reinganum, 1989). Its applicability is significant in Pakistan where the traditional banks are almost inexistent (Buckley \& Webster, 2016).

The notion of value co-creation under SD logic has gained prominence in the information system broadly (Breidbach \& Ranjan, 2017) and particularly in Service Science (Maglio \& Breidbach, 2014). This SD logic can be related to the BB but there is the dearth of research while linking FinTech with the landscape of the Service System (Breidbach \& Ranjan, 2017). It has been criticized that they "failed to offer insights on emerging digital service innovations" (Lusch \& Nambisan, 2015, p. 172).

SD logic idea of value co-creation can very well be linked with the BB. For example, Easypaisa that lends and the borrower or sale purchase occurs via them, meeting the criteria of value co-creation. Today service system, value-co creation as well as FinTech concepts are of utmost importance to IS researchers (Breidbach \& Ranjan, 2017). The failure to truly assess the needs of local customers brings FinTech failure (Buckley \& Webster, 2016). However, developed countries have met this target. There is a need to study the customer's journey in developed countries for two reasons; startups have proved FinTech as a printable enterprise, Secondly, it has the potential to thrive the financial inclusion in developing countries (Buckley \& Webster, 2016). So far financial institutions have failed to study the customer in-depth needs of customers. FinTech has now come to fill the breach. Financial inclusion can be increased by making financial products and services easy to use, it may introduce financial products to more public. Developed and developing countries have contrasting scenarios where former have high institutional quality, the latter is the victim of a vicious cycle where there is low access to financial services which leads to financial literacy and people are stressed to use informal loans (Meyer \& Schwager, 2007).

Financial literacy is low in Pakistan. being a developing country, people above 25 of age have a 13\% bank account (Global Voice \#8: Special Asia-Pacific issue, 2019). Financial literacy leads to high financial inclusion and vice versa and can bring low frauds in availing financial services/products. People have difficulty in availing loans from microfinance whose basic agenda is to eradicate poverty. But the repayment is quite difficult which leads to irretrievable poverty. However, difficulty in attaining the loans and high interest rate leads to the informal credit source from friends and relatives as per world bank people's poorest households lack bank accounts (Demirgüç-Kunt, Klapper, Singer, Ansar, \& Hess, 2020). Information asymmetry and transaction costs are said to be the main hurdles in obtaining access to credit (Buckley \& Webster, 2016).

Social Networking Sites (SNSs) such as Facebook, Twitter, and YouTube have become most favored platforms to share their experiences and views about service availed by consumers to develop and consume branded content formally known as the brand post (Waqas et al., 2020). Many people make regular use of Social Networking Sites (SNSs), which have become central to the lives of individuals. The number of Facebook users, the most famous SNS, serves as evidence. In early 2008, there were about 69 million active users worldwide, whereas, in the first quarter of 2020, the number had grown to more than 2.6 billion (Statista, 2020)

In the present study, Facebook is selected for netnograpghy to have a cultural understanding of community members of online lived shared experiences. Facebook has the 2.6 billion users worldwide (Statista, 2020) making it the world's most popular medium to engage with brands as it displays the highest inter member interactions and traffic of online posts (Coombes \& Jones, 2020). There are three metrics of selecting brand communities and 
knowing engagement of users numbers of 1) comments, 2) likes, 3 ) followers (de Brito Silva, de Farias, Grigg, \& de Azevedo Barbosa, 2019).

However, the extant literature does not suggest what are the antecedents and consequences of the critical incidents that lead the consumer to share his/her experience on social media sites such as Facebook. The eventual consequence is either value co-creation or value co destruction by keeping the outcomes of the ISPAR model. However, an extensive review of current literature depicts that there is a scarcity of studies on the analysis of netnographic critical incidents in BB experience. Moreover, the research gap exists to find out the consumers' perspective on the touchpoints that either help to co-create or co-destruct the value. BB is a new avenue in the financial service sector. The financial literacy of consumers might be different which can produce different outcomes of service availed. There can be several other factors as well which can have a good or bad experience. So the study will be helpful for the BB institutes and consumers as well to find out the antecedents of value cocreation and value co-destruction. Moreover, the ISPAR model will be a new contribution in $\mathrm{BB}$ which provides ten outcomes where value is either realized or value is not realized. This study will provide the impetus to study all the outcomes and antecedents that cause such outcomes. However, the focus of this study is only on outcomes R, K, W, -P, -A, -K.

\section{RESEARCH METHODOLOGY}

Netnographic research has attracted the interest of researchers from interdisciplinary research but it is still not extensively used (Coombes \& Jones, 2020). Netnography is used to produce rich extensive narrations present in the consumer shared experiences providing comprehensive lived online experiences of members of brand communities (Coombes \& Jones, 2020; Kozinets, Scaraboto, \& Parmentier, 2018).

It demands from the researcher to conduct participatory observation on an extended period (online brand communities, newsgroups, inline bulletin boards, blogs, and other online forums, etc) and online interviews for deep insight into the phenomenon of interest (Wang, 2019). Netnographic research is qualitative ethnographic research that explores the online culture of brand community members (Kozinets et al., 2018). It is established that netnographic research is appropriate to study consumers' lived experiences with the brand which aids in adding up the new branded content from emerged themes (Coombes \& Jones, 2020). The unit of analysis for the current study is the whole experience, with the boundaries defined by the participants. Therefore, the CIT has deemed a suitable data collection method by having the participants tell their personal experiences of value co-creation and/or destruction in their own words, which are either positively or negatively memorable.

Three major stages comprise the CIT analysis: collecting and assembling data, analyzing data, and constructing an explanatory framework. The three stages are further divided into the following six steps:

- data collection;

- development of coding categories;

- classification of incidents or parts of incidents into categories;

- identification of trends in the data;

- data reduction; and

- explanation of the underlying structure to develop propositions. 


\subsection{Data Collection Procedure}

Netnographic research had been conducted by selecting the critical incidents shared by community members of BB Facebook brand communities. Themes were extracted from the posts by using Nvivo 12 plus. Themes showed the antecedents and consequences of value cocreation and value co-destruction based upon the outcomes of the ISPAR model. The current study follows the steps proposed by (Kozinets, 2002) of netnography. Firstly, the researchers browsed all possible online BB brand communities of companies. Secondly, online brand communities were screened based on the number of likes, scrutiny of daily posts posted on pages by online members of those communities, the topic being discussed as the major focus of the researchers was on the critical incidents shared. Then the communities were selected that met the criteria. Thirdly, an online consent letter was sent to the administrators of selected brand communities. Fourthly, the researcher read all comments, reviews, posts for three months also participated in posts without asking any question by being participatory observer by browsing over such a large number of posts, the vivid picture of possible critical incidents shared by members were explored. The critical incident is defined as "a situation or event that stands out for its characteristics, which make it critical, distinct and relevant to the understanding of a given phenomenon or process" (Flanagan, 1954).

Meeting the general requirement of netnography, theoretical sampling was used as all posts were included collecting data until the saturation point was reached (Lee, Saunders, \& Goulding, 2005). Archival data in the form of comments on branded content posted on BB brand communities were collected which represented critical incidents. Data were recorded by copying comments from the brand communities and pasting them on MS Word document. This manual extraction of data allowed real-time engagement with the cultural context which makes it better than the data-mining programs (Kozinets, Dolbec, \& Earley, 2014). Then data cleaning was done by removing the unnecessary noisy information not required keeping the research questions into consideration. Afterward, the files were uploaded on NVivo 12 plus.

\subsubsection{Steps of Data Collection and Analysis}

In qualitative research using online social media, first of all, the characteristics of data have to be decided (de Brito Silva et al., 2019), the author has selected the reviews and posts of users of online brand communities. The next step comprised of selecting the content of posts, the Critical Incident Technique (CIT) was used and adapted in online study. This CIT can be used in a wide variety of ways such as the collection of data from interviews, observations openended questions (Fridlund, Henricson, \& Mårtensson, 2017). In the present study, the author became a participatory observer making CIT viable. All those comments, posts, reviews that were initiated based upon some event or incident made it possible to observe the cognitive, emotional and cognitive response of the brand users, For this reason, the comments of the posts were collected, totaling the observation of comments in posts.

Table 3 Select brand communities of Branchless Banking

\begin{tabular}{llcc}
\hline \multicolumn{1}{c}{ Name } & \multicolumn{1}{c}{ Collection period } & Codes & Collected posts \\
\hline Alfa & $1^{\text {st }}$ April 2020-31 $1^{\text {st }}$ June 2020 & 22 & 151 \\
Easypaisa & $1^{\text {st }}$ April 2020-31 $1^{\text {st }}$ June 2020 & 60 & 2145 \\
Jazz Cash & $1^{\text {st }}$ April 2020-31 $1^{\text {st }}$ June 2020 & 40 & 597 \\
KONNECT & $1^{\text {st }}$ April 2020-31 $1^{\text {st }}$ June 2020 & 42 & 490 \\
UBL & $1^{\text {st }}$ April 2020-31 $1^{\text {st }}$ June 2020 & 29 & 368 \\
Upaisa & $1^{\text {st }}$ April 2020-31 ${ }^{\text {st }}$ June 2020 & 6 & 9 \\
\hline
\end{tabular}


Therefore, this useful technique has been used in analyzing the online content from the $\mathrm{BB}$ perspective. The analysis of online shared Critical Incidents (CI) met the following criteria

Definition of CI: The comments were categorized as CI as receiving the highest number of likes, comments, and positive and negative feedback from members.

Collection of CI: The extreme emotional, cognitive, and behavioral responses by members on posts or reviews were pasted on Microsoft word and noisy data was removed by the data cleaning process.

Categorization of CI: The thematic content analysis was performed of the selected incidents by coding terms in significant categories. (de Brito Silva et al., 2019)

\subsection{Findings from Netnographic Analysis of Critical Incidents}

The posts were analyzed using CIT as the main purpose of the study was to find the antecedents that led to the critical incidents and consequences of those incidents. The comments, posts, reviews were identified, classified, and then categorized inductively. The spelling errors in comments by community members have been corrected at some place by researcher to make meaning clear. no expression or verbatim has been changed. Moreover, in the following excerpts stated in analysis, the names of $\mathrm{BB}$ service providers have been omitted deliberately to not breach issue of confidentiality.

\subsubsection{Value co-destruction}

Our study identified the cases that pose challenges to Branchless Banking service providers eventually creating value co-destruction:

One salient triggering point is described in the following critical incidents is the nonprovision of service promised by the service provider;

"Highly unprofessional organization. They recently blocked account without knowledge if reason. I unblocked one but the second one is not blocking. They promised to call but did not do it. How unprofessional"

"Very Pathetic service. They promised to deliver my ATM Card in 15 days but they are not able to deliver even after 1 month."

The other comment by one of the aggrieved beneficiary is as follows:

This is a pathetic app I have ever experienced in my life. I will never ever recommend anyone to use this app. No satisfactory response from representatives. I invited three of my friends in Feb to sign up they created account and did transactions accordingly however I did not receive any award. Every-time I call to....... customer help they ask for details and log complaint but nothing happens. Again I called another representative talked and he asked same credentials nothing happens. Besides we spend lot of our mobile balance to talk to them and nothing happens. Even I have emailed to you multiple times but no satisfactory response

Other encounters that came up through the analysis is the deduction of amount without telling the beneficiary, one such instance is as follows:

"They are fraud fake company. They rob small amounts. Please report their Facebook page, give bad ratings on app store and complain in cybercrime. They have done such scams to many people".

"no security protection .. someone stole my money 20000 and company is so lame that they can't do anything ... such an act of shame. I think they must stop providing services... pathetic customer services". 
Assessment of Financial Technology Services for Value Co-creation or Value Co-destruction in Emerging Economies: ISPAR Model

"They rob small amounts from your account for which you will not take legal action. please complain against them in cyber cell if you faced the similar scam. I purchased Careem topup voucher of Rs. 1000 from......."

In this vein, we also found that no response from the service provider is one of the most important points that does not create value from the perspective of the customer:

"They will keep asking u to inbox no matter how many times you've. the info previously. They are fraud \#Boycott......."

“..... is a fraud and time waste and very poor customer service and support team and very unhelpful and a totally bullshit service provider"

"No voucher received. I've spend around PKR 1000 credit by calling their helpline where they kept me hold for average 20 mins. Registered around 10 complaints, they promised to call me back but no call received."

I don't recommend ............ two times my money has been paid to some ghost company automatically. upon my complaint it was said that we are looking into the matter however nothing has been done and it happened again. I complained again and they said we are still looking in to the matter. it is . a scam. they are drawing your money. keep record of your transactions

Similarly, another issue faced by customers is third party fraud which on the name of service provider robs amounts by pretending to be real company. This comes under cybercrime. The complaint by customers is that companies are doing nothing despite thousands of rupees are being taken on their names

The day (8 May 2020) I activated ....... account on my ...... number, I have been receiving calls from scammers to send them OTP numbers and all those lame excuses that we sent you the message by mistake etc. Return the message within $30 \mathrm{se}$........don't recommend ...... two times my money has been paid to some ghost company automatically. upon my complaint it was said that we are looking into the matter however nothing has been done and it happened again. I complained again and they said we are still looking in to the matter. it is. a scam. they are drawing your money. keep record of your transactions.

Initiation of service system process: for many issues, despite resolving the issue; the service provider initiates the process by just apologizing or asking customers to send their details via inbox, etc. which create a nuisance as per the customers.

"we understand your discontent and apologize for the service issue that you are experiencing. If you have received your debit card yet, kindly . ..... Account number and transaction ID related to debit card with us. We will check and surely resolve your concern".

"We regret the inconvenience you might have faced. Please note that resolution time depends upon the nature of issue. You can always write to us via inbox for earliest assistance".

As discussed earlier, this is frustrating for the customers:

"If u complain, it will ask every time for sharing details in inbox but nothing to do for help. They just ask to contact via inbox because they don't want to disclose customers complain in front of other customers".

"I vibe quite a few times but it has not happened yet, so I am very angry on this".

The synthesis of findings shows that factors that lead to the value co-destruction are poor service provision, unhelpful and unprofessional helpline, and technical glitches relating delay in realization of value. 


\subsubsection{Value co-creation}

It has been observed that value is co-created when the service provisions are done in time. few of the excerpts from comments are given below:

"kind, top-up , paying bills, donations and insurances in Pakistan and it always amazing us by its unique and valuable services and offers, convenient mode of payment for its customer..scan pay go, no need to carry cash, no threat of misuse . in transactions are ....ized by customer t-pin...many things done at home specially during lockdown situation"

Similarly, the issue resolved instantly is the source of value co-creation:

"Dear ......, thank you for your feedback. Please note that you are facing a "Cache Error" issue, kindly go into the phone settings and select the App and tap Clear data and Clear cache option and once that is done, please try logging again and you will."

The implementation of technical glitches free IT system, incorporating a robust security system, clearly guiding the customers, resolving their issues instantly pave the path for value co-creation. The consequences of value co-creation are the positive word of mouth shared on social media, appreciation, and motivation to use the service again in the future as well. They feel contented and satisfied eventually retention of consumers increases.

Themes identified from netnographic analysis:

Following are the critical incidents identified from netnographic analysis:

- Bounced payment

- Charged extra fee

- Rude service encounter

- Slow network

- Significant changes in charges

- App stopped working

- Fraud

- Cybercrime

- Deduct charges

- Blocked account without informing

- No service provision for the amount charged

- Third-party fraud

- Privacy breached to third party scammers by employees

- Trouble opening account

- Abusive language by customer

After that, the themes were then categorized as the events led to either value co-creation or value co-destruction. After this, the categories were placed into ISPAR model as per the outcome of those themes. Then the antecedents and consequences of these critical incidents were identified and placed in the outcomes of the ISPAR model. Only those outcomes were taken which take to vale co-creation or value co-destruction. 
Assessment of Financial Technology Services for Value Co-creation or Value Co-destruction in Emerging Economies: ISPAR Model

Table 4 Themes from Netnographic analysis categorized as per ISPAR model

\begin{tabular}{|c|c|}
\hline $\begin{array}{l}\text { Value co-creation } \\
\text { OK for interested }\end{array}$ & \\
\hline Antecedent & \\
\hline Instant resolve issue & 7 \\
\hline Quick feedback & 3 \\
\hline Consequence & \\
\hline Satisfaction & 7 \\
\hline Realization & \\
\hline Antecedents & 118 \\
\hline All in one service & 10 \\
\hline Contact by the service provider & 11 \\
\hline Earning app.-R & 2 \\
\hline Easy to use-R & 21 \\
\hline Helpful during lockdown & 16 \\
\hline Professional & 14 \\
\hline Quick service & 7 \\
\hline Security & 16 \\
\hline Top-ups-R & 14 \\
\hline Useful & 7 \\
\hline Consequences & \\
\hline Appreciation & 48 \\
\hline Motivated & 9 \\
\hline Recommended & 155 \\
\hline Satisfaction & 83 \\
\hline Thankful & 179 \\
\hline Welcome & \\
\hline Antecedent & \\
\hline Feedback & 44 \\
\hline Inform about services & 42 \\
\hline Motivational conversation & 62 \\
\hline Respect & 167 \\
\hline Consequence & \\
\hline Happy & 4 \\
\hline Thankful & 207 \\
\hline Value co-destruction & \\
\hline Agreement not reached & \\
\hline Antecedents & \\
\hline Better options & 3 \\
\hline Delay in service provision & 15 \\
\hline Privacy issue & 2 \\
\hline Service enforcement & 5 \\
\hline Suspend account & 3 \\
\hline Technical glitches & 6 \\
\hline Unhelpful customer service & 22 \\
\hline Employees receive a commission from the scammer & 2 \\
\hline Trouble opening account & 3 \\
\hline Consequences & \\
\hline Apology-initiation & 19 \\
\hline Frustration & 4 \\
\hline Not OK for interested & \\
\hline Antecedents & \\
\hline Low rating on the app & 3 \\
\hline Not recommended & 63 \\
\hline Report on Social Media & 8 \\
\hline Consequences & \\
\hline
\end{tabular}




\begin{tabular}{lc}
\hline Abusive language by customer & 3 \\
\hline Dispute & 5 \\
\hline Proposal not accepted & \\
\hline Antecedents & 7 \\
\hline Change rules without informing & 3 \\
\hline Misguide & 25 \\
\hline No response & 44 \\
\hline Poor helpline & 16 \\
\hline Wait on call & 2 \\
\hline Consequences & 2 \\
\hline Switch to another brand
\end{tabular}

Evidently, the implementation of technical glitches free IT system, incorporating a robust security system, clearly guiding the customers, resolving their issues instantly pave the path for value co-creation. Both upstream and down-stream processes need to be error-free by BB to improve the quality of service provision.

\section{CONCLUSIONS AND IMPLICATIONS}

The significance of value co-creation is well documented in the domain of Service-Dominant Logic. The outcomes in the form of value co-creation or value co-destruction can be understood by following the ISPAR model, but what are the triggering incidents that caused the outcomes earlier discussed in this section is still under investigation. The study conducted is an attempt to analyze the critical incidents by using netnography by focusing on one of the categories of FinTech i.e., branchless banking from the perspective of Pakistan. Financial literacy is low in Pakistan. Being a developing country, people above 25 of age have a 13\% bank account (Global Voice \#8: Special Asia-Pacific issue, 2019). Financial literacy leads to high financial inclusion and vice versa and can bring low frauds in availing financial services/products (Abidin \& Roziana, 2019). BB is an efficient mode to reach to people in remote areas where transactions by people are small, banking access is difficult (Kustina et al., 2019), areas with low population density, availing financial services is costly id done via formal banks and literacy rate is low (Kustina et al., 2019).

Building on the critical incident perspective of customers' experiences, the study comes up with the themes representing the antecedents and consequences of value co-creation and value-co destruction. The most popular brand communities of branchless banking had been selected where the number of posts and likes were maximum. The posts meeting the criteria of critical incidents were selected. Also, the complete procedure of netnographic research was met as given by Kozinets (2002).

The most frequent critical incidents faced by customers were the deduction of small amounts from the Branchless Banking account without informing the customer. When the service provider is contacted, they despite coming to any outcomes of the ISPAR model they initiate the service system process again and then disappear without resolving the issue of customers. The other major event which has to face in BB is third party fraud which according the netnographic analysis very much prevalent in Pakistan but service providers show failure in resolving it.

The consequence of it is then the value co-destruction as per the ISPAR model, comprising outcomes $-\mathrm{A},-\mathrm{P},-\mathrm{R}$. the possible outcome is proposal understood, disagreement of the proposal, or value not realized the findings. The major and unique observation is that rather than resolving the issue, customers say that they are kept on waiting either by apology or contacting the service provider. So despite coming to some service outcome, service providers initiate the service process by apology or asking for details. The customers 
complain that they do not receive any response after that apology or even after sending them the beneficiary's details.

The antecedents and consequences of value co-creation identified in critical incidents have also been discussed. The most prevalent factors that cause value co-creation are the benefit of all the necessary BB services under one window, easy to use BB services, proper feedback from the service providers, the respect in overall financial service journey. So it can be observed that the professional attitude of customer service is very important in value cocreation otherwise it can create disputes.

Overall, it can be concluded that BB is still in its nascent stage and requires focusing on the nitty-gritty to make the financial journey of the customer pleasant. People in Pakistan who use BB belong to the mediocre social class for whom a small amount of money holds great significance. If they lose their amount due to any reason such as third party fraud or deduction of charges without informing them makes the beneficiary very frustrated and the consequence can be switching to other service providers or negative word of mouth especially on social network sites. As there is a big audience of Social Networking Sites (SNSs), the impact of each word said via posts or comments holds huge importance. The social media interaction enables us to make others aware of the experience of brands as users so their firsthand experience on SNNs.

\section{THEORETICAL CONTRIBUTION}

The current study theoretically contributes to the existing state of knowledge in several ways. First, a service-dominant logic lens was applied in FinTech by focusing on branchless banking. The outcomes are measured in terms of the ISPAR model by using netnographic analysis which is unique in its theoretical contribution, secondly, the study helps to understand the critical incidents by deeply going into the antecedents of successful or unsuccessful interaction with BB. The themes emerged by focusing on the emotional, cognitive, and behavioral aspects of the events explained by the members of brand communities.

\section{MANAGERIAL IMPLICATIONS}

The study has implications for managers as well, the managers can equip themselves with the distinctive evens that can either co-create value or co-destruct it. By knowing the story of both ends, mangers can help to polish the customers' touchpoints in BB. In this era of globalization, BB is flourishing sue to its multiple benefits. They need to create pleasing, amazing, and problem-solving processes for the beneficiaries. Managers need to make sure that they create a positive experience for customers so whatever they share on SNSs helps to create positive word of mouth for the service providers.

\section{LIMITATIONS AND FUTURE RESEARCH}

Despite its contribution, this study is subject to some limitations. First, the study was limited to only BB, so can't be generalized to other categories of FinTech, secondly, netnography has been used, a qualitative research technique. Other methods such as interviews can also be conducted for cross-validating the critical incidents. Future research may focus on quantitative research using the ISPAR model. Moreover, in the present study, the focus was on only in the value co-creation and value co-destruction outcomes. Other outcomes such as J, $-J$, -D , -C have not been analyzed. Then users' comments are analyzed for three months, however, interested researchers may extend it for a longer period. Data is collected from Facebook only. This limitation can be removed by focusing on other SNSs as well. 


\section{REFERENCES}

[1] Abidin, T. Z., \& Roziana, T. (2019). The relationship between financial inclusion and financial stability in Muslim countries in comparison with OECD countries: the role of institutions.

[2] Ackoff, R. L. (1971). Towards a system of systems concepts. Management science, 17(11), 661-671.

[3] Behr, P., Entzian, A., \& Güttler, A. (2011). How do lending relationships affect access to credit and loan conditions in microlending? Journal of Banking \& Finance, 35(8), 2169-2178.

[4] Borangiu, T., Oltean, V. E., Drăgoicea, M., e Cunha, J. F., \& Iacob, I. (2014). Some aspects concerning a generic service process model building. Paper presented at the International Conference on Exploring Services Science.

[5] Breidbach, C. F., \& Ranjan, S. (2017). How do Fintech Service Platforms Facilitate Value Co-Creation? An Analysis of Twitter Data. Paper presented at the ICIS.

[6] Buckley, R. P., \& Webster, S. (2016). FinTech in developing countries: charting new customer journeys. Journal of Financial Transformation, 44.

[7] Chen, R., \& Divanbeigi, R. (2019). Can Regulation Promote Financial Inclusion? : The World Bank.

[8] Clark, H. A. (2020). Introduction: Building the Future-Beyond Borders, Beyond Banking. In Beyond Borders, Beyond Banking (pp. 3-9): Springer.

[9] Coombes, P. H., \& Jones, S. (2020). Toward auto-netnography in consumer studies. International Journal of Market Research, 1470785320923502.

[10] de Brito Silva, M. J., de Farias, S. A., Grigg, M. H. K., \& de Azevedo Barbosa, M. d. L. (2019). The online engagement and the role of digital influencers in the product endorsement on Instagram. Paper presented at the CLAV 2019.

[11] Demirgüç-Kunt, A., Klapper, L., Singer, D., Ansar, S., \& Hess, J. (2020). The Global Findex Database 2017: Measuring Financial Inclusion and Opportunities to Expand Access to and Use of Financial Services. The World Bank Economic Review, 34(Supplement_1), S2-S8.

[12] Flanagan, J. C. (1954). The critical incident technique. Psychological bulletin, 51(4), 327.

[13] Fridlund, B., Henricson, M., \& Mårtensson, J. (2017). Critical Incident Technique applied in nursing and healthcare sciences. SOJ Nursing \& Health Care, 3(1), 1-5.

[14] Global Voice \#8: Special Asia-Pacific issue. (2019). ESSEC Business School, 2019.

[15] Gummesson, E., Mele, C., Polese, F., Breidbach, C. F., Brodie, R., \& Hollebeek, L. (2014). Beyond virtuality: from engagement platforms to engagement ecosystems. Managing Service Quality.

[16] Hsu, S. H.-Y., \& Yen, H. R. (2016). Predicting good deeds in virtual communities of consumption. Internet research.

[17] Kozinets, R. V. (2002). The field behind the screen: Using netnography for marketing research in online communities. Journal of marketing research, 39(1), 61-72.

[18] Kozinets, R. V., Dolbec, P.-Y., \& Earley, A. (2014). Netnographic analysis: Understanding culture through social media data. The SAGE handbook of qualitative data analysis, 262-276. 
Assessment of Financial Technology Services for Value Co-creation or Value Co-destruction in Emerging Economies: ISPAR Model

[19] Kozinets, R. V., Scaraboto, D., \& Parmentier, M.-A. (2018). Evolving netnography: How brand auto-netnography, a netnographic sensibility, and more-than-human netnography can transform your research. In: Taylor \& Francis.

[20] Kustina, K. T., Dewi, G. A. A. O., Prena, G. D., \& Suryasa, W. (2019). Branchless banking, third-party funds, and profitability evidence reference to banking sector in indonesia. Kustina, Ketut Tanti, Dewi, Gusti Ayu Agung Omika, Prena, Gine Das and Suryasa, Wayan, Branchless Banking, Third-Party Funds, and Profitability Evidence Reference to Banking Sector in Indonesia (February 20, 2019). Jour of Adv Research in Dynamical \& Control Systems,(11), 2, 290-299.

[21] Lee, N., Saunders, J., \& Goulding, C. (2005). Grounded theory, ethnography and phenomenology. European journal of Marketing.

[22] Linsenmeier, D. M., Rosen, H. S., \& Rouse, C. E. (2006). Financial aid packages and college enrollment decisions: An econometric case study. Review of Economics and Statistics, 88(1), $126-145$.

[23] Lusch, R. F., \& Nambisan, S. (2015). Service innovation: A service-dominant logic perspective. MIS quarterly, 39(1), 155-176.

[24] Maglio, P. P., \& Breidbach, C. F. (2014). Service science: toward systematic service system innovation. In Bridging Data and Decisions (pp. 161-170): INFORMS.

[25] Maglio, P. P., \& Spohrer, J. (2008). Fundamentals of service science. Journal of the academy of marketing science, 36(1), 18-20.

[26] Malik, M. (2020). Elements Influencing the Adoption of Electronic Banking in Pakistan An investigation carried out by Using Unified Theory of Acceptance and Use Technology (UTAUT) Theory. Journal of Internet Banking and Commerce, 25(2), 1-24.

[27] Meyer, C., \& Schwager, A. (2007). Understanding customer experience. Harvard business review, 85(2), 116.

[28] Mora, M., Gelman, O., Cervantes, F., Mejía, M., \& Weitzenfeld, A. (2003). A systemic approach for the formalization of the information systems concept: why information systems are systems? In Critical reflections on information systems: A systemic approach (pp. 1-29): IGI Global.

[29] Mora, M., Raisinghani, M. S., O'Connor, R., \& Gelman, O. (2009). Toward an integrated conceptualization of the service and service system concepts: A systems approach. International Journal of Information Systems in the Service Sector (IJISSS), 1(2), 36-57.

[30] Moro Visconti, R. (2020). Fintech Valuation. Available at SSRN 3533869.

[31] Prahalad, C. K., \& Ramaswamy, V. (2004). Co-creation experiences: The next practice in value creation. Journal of interactive marketing, 18(3), 5-14.

[32] Qazi, S. W., \& Khushk, H. A. (2019). Fueling Women Empowerment?: A Phenomenological Study of Women Experiences with Micro-Credit and Status of Branch-less Banking in Pakistan. International Journal of E-Business Research (IJEBR), 15(1), 75-88.

[33] Reinganum, J. F. (1989). The timing of innovation: Research, development, and diffusion. Handbook of industrial organization, 1, 849-908.

[34] Rojas-Suarez, L. (2010). Access to financial services in emerging powers: Facts, obstacles and recommendations. Obstacles and Recommendations (March 2010). 
[35] Statista. (2020). Retrieved from https://www.statista.com/statistics/278414/number-ofworldwide-social-network-users/

[36] Vargo, S. L., \& Lusch, R. F. (2004). Evolving to a new dominant logic for marketing. Journal of marketing, 68(1), 1-17.

[37] Wang, C. L. (2019). Handbook of Research on the Impact of Fandom in Society and Consumerism: IGI Global.

[38] Waqas, M., Hamzah, Z. L., \& Salleh, N. A. M. (2020). A typology of customer experience with social media branded content: a netnographic study. International Journal of Internet Marketing and Advertising, 14(2), 184-213.

[39] Zaffar, M. A., Kumar, R. L., \& Zhao, K. (2019). Using agent-based modelling to investigate diffusion of mobile-based branchless banking services in a developing country. Decision Support Systems, 117, 62-74. 